\title{
Moral boundaries of beauty
}

Reflection on beauty should also consider the moral aspects, and therefore the relationship to good. The relationship between beauty and good indicates Hebrew and Greek terminology, which is the same word (heb., tob, gr. kalos, agathos) that determines both beauty and good. In the Aristotelian-Thomistic concept every being is beautiful and also good because it has its source in God's creative action. Due to the ongoing today subjectivisation and relativism of beauty it should be emphasized that this title is worth only what reflects eternal beauty. Therefore, not everything is beautiful what a man creates and what as such is considered. Beautiful is what is good and what leads to goodness. Beyond this limit imposed by the good exists only apparent beauty, and even ugliness, which is sometimes called beauty, but it is not. Striving toward eternal beauty, creating beauty within and around each other, growing up in beauty is a moral duty of a man.

Key words: beauty, goodness, morality.

The subject of beauty is an essential part of considerations about art and its various fields - poetry, literature, painting, sculpture, architecture, music, theater ${ }^{1}$. In theology, this issue arises mainly in connection with a reflection on the Christian art and the space, which for art is liturgy. It seems that in a reflection on the beauty it is needed to go beyond the traditional aesthetic approach towards a more interdisciplinary, which means appreciating the theological-moral prospects. This aims to assess the human and his activities in terms of good and

Cf. John Paul II, Letter to the Artists (hereinafter: LtoA) 3. Cf. also: Piękno, [in]: H. Vorgrimler, Nowy Leksykon Teologiczny, transl. T. Mieszkowski, P. Pachciarek, Warszawa 2005, p. 264. 
Moral theology

evil. This judgment is made by the confrontation with the standard (also derived from Revelation), and is based on compliance or noncompliance with it, human action and its author, so the man himself gets the label of a good or a bad one.

In theological-moral reflection on beauty, therefore, there is a crucial question: Is beauty good or bad? Is its creator good or bad? Are there any moral boundaries of beauty, beyond which it becomes only apparent beauty, or even ugliness?

These are ultimately questions about the place of beauty in the moral life and theological reflection on this life. The answer to these questions is only possible in the light of beyond aesthetic criteria and those criteria are demanding determination.

\section{Beauty is good}

A reflection on the moral boundaries of beauty should begin with the fundamental statement: beauty is good. It is - at least in the Aristotelian-Thomistic concept - a direct and conical feature of being and crowns its all other intrinsic properties. Therefore, it can be said that everything that exists, every being is beautiful in its own way, although the degree of this beauty will depend on the participation in life; a material object, an animal or a man would be beautiful in a different way ${ }^{2}$. In the triad of the highest values (beauty - the truth - good) beauty is considered a synthesis of all transcendentals.

Scripture reveals many exemplifications of beauty as an ontological category. Beauty is the majesty of God ( $2 \mathrm{Kgs} \mathrm{7,21;} \mathrm{Isa} \mathrm{64,10)} \mathrm{and} \mathrm{His}$ revelation (cf. $1 \mathrm{Chr} 16,27$; Ps 96,6) (in the NT mainly revelation on Mount Tabor - cf. Matt 17,1-13; Mark 9,1-7; Luke 9,28-36). Beauty is an attribute of people: Sarah, the wife of Abraham (cf. Gen 12, 11. 14), Joseph (cf. Gen 39, 6), Moses (cf. Exod 2,2), Rebecca (Gen 24,16; 26,7), Abigail, Nabal's wife (cf. 1 Sam 25,3), Bathsheba, the wife of Uriah (cf. 2 Sam 11,2), David (cf. 1 Sam 16,12. 18), Abishag (1 Kgs 1,4). Beautiful are the "daughters of men", who were taken to be a wife of the sons of God (cf. Gen 6, 2). "Extraordinary beauty" were also Adonijah (cf. 1 Kgs 1,6), Absalom (2 Sam 14, 25), the prophet Ezekiel (cf. Ezek. 33,32), Esther (cf. Esth 2,7), Susanna (cf. Dan 13, 2. 31), the bridegroom and the bride of the Song of Songs (cf. Song 1,15-16), virgins and young men from the punishment announced by the prophet Amos (cf. Amos 8,13). Geographic regions also have the attribute of beauty: eg. Assyria (cf. Ezek. 31,7); the words, eg. David (cf. Ps. 45,2), Ecclesiastes (cf. Eccl 12,

2 Cf. Piękno, [in]: H. Vorgrimler, Nowy leksykon teologiczny, p. 264. 
10), sages (cf. Prov 22, 38). This feature is entitled to things produced by men: the embroidered curtain of the temple (cf. Exod 26,31), clothing (cf. Josh 7,21), the spoils of war (cf. 1 Sam 15, 9), the tents of Jacob (cf. Num 14,5), the houses of Israel (cf. Deut. 8,12). Beautiful are the mountains (cf. Deut. 3,25), the vineyards (cf. Amos 5,11), the cedars of Lebanon (cf. Ezek. 31,3), animals (cf. Gen 18,7) ${ }^{3}$.

According to the Bible, the genesis of beauty is a creative action of God (cf. Eccl 3,11; Sir 39,16; Gen 1,4. 10. 12. 18. 21. 25. 31). Referring to the biblical texts of many Christian authors (led by St. Augustine) it is recognized that theokalia is the original source of all good and beauty ${ }^{4}$, and beautiful objects and people are as traces of intangible beauty. According to these authors, a man can discover and admire beauty only when he knows its source - the transcendent beauty of God ${ }^{5}$. Knowing this is possible because beauty produces a kind of glow that the Bible calls "glory". Charm radiating from every beauty is also nothing but grace (gr. charis) ${ }^{7}$. Therefore, beauty represents a real value. It manifests itself in various wonders of nature and speaks the language of art. Its source is God, and therefore it is also good. No wonder that the ancients used the common term for these two realities - both beauty and good known as kalokagathia ${ }^{8}$. Beauty is good. "The power of good - as Plato said - took refuge in the nature of beauty". That is why beauty can manifest good; it is its visibility ${ }^{10}$. Although good and beauty are different properties, they are together: beautiful things are good and good - beautiful. In the Scriptures, however, and especially in the Gospels, there is often the Greek word kalos, it is probably not in the aesthetic but moral sense. Beauty is clearly connected there with the good act committed; the action inspired by love and faith ${ }^{11}$. Such an act is defined not only as good, but also as beautiful; it is a manifestation of beauty. A mani-

3 Cf. K. Klauza, Piękno, 1. W teologii, [in:] Encyklopedia katolicka, E. Gigilewicz et al. eds., vol. 15, 561 .

4 Cf. John Paul II, Apostolic Letter Augustinum Hipponensem 4.

Cf. John Paul II, General Audience, Evidence for the existence of God (10.07.1985) 6.

Cf.D. Mollat, Chwata,[in]:Stownik Teologii Biblijnej, X. Léon-Dufour ed., transl.

K. Romaniuk, Poznań 1994, p. 135.

7 Cf. J. Guillet, Łaska, [in]: ibidem, p. 437.

8 LtoA 3

$9 \quad$ Cf: LtoA 3.

10 Ibidem.

11 Cf.Ewolucja teologii piękna,http://katechetyka.diecezja.opole.pl/2014-arcydziela/04-teologia.pdf, p. 43 (30.03.2016). 
festation of beauty, and even more - its metaphysical condition ${ }^{12}$ is also good contained in the moral attitudes, virtues and especially in love. Therefore, the claim that "beauty is good" is true only if beauty is understood as a real value and not eg. a subjective perception of that value. The claim must be complemented by another one, namely, that: beautiful is that what is good and consequently it is good.

Moral

\section{Good is beautiful}

The relationship between good and beauty is already shown in the terminology. Hebrew term "tob" (good) is interchangeably translated in Greek into two terms: kalos and agathos - beautiful and good, and indicates a person or an object causing pleasant sensations or a kind of bliss; everything that is the cause of happiness and makes life easier in the physical or psychological order; on the contrary, everything that leads to diseases and causes suffering of all kinds, and especially death, is evil (heb. ra, gr. poneros and kakos) ${ }^{13}$.

Originally, the concept of beauty included not only the aesthetic, but also moral phenomenon. Even Socrates, the Platonism (and the entire Christian tradition with them), emphasize the community of beauty and moral good, allowing to identify good deeds as "beautiful"14. This term deserves also moral attitudes, noble feelings and wonderful gesture ${ }^{15}$. Moreover, "beautiful" acts are the subject of the commandments (cf. Luke 6,27.35: "do good [kalos poieite] those who hate you"). At the same time a man realizes that this beauty was "given" to him, even if he cooperates in giving him the expression ${ }^{16}$.

The beauty of good points Scriptures assigning a category of beauty to moral attitudes, and especially to love. "How beautiful is love!" - delights the bridegroom from the Song of Songs (4,9-10). This term ("beautiful love") has found a prominent place in the contemporary theology, especially the theology of marriage and family $\operatorname{life}^{17}$. Moreover, the term

$12 \quad$ Cf. LtoA 3.

13 Cf. J. de Vaulx, Dobro i zło, [in]: Stownik Teologii Biblijnej, X. Leon-Dufour ed., p. 207.

14 Cf. L. Gawor, Piękno, [in:] Maty stownik etyczny, S. Jedynak ed., Bydgoszcz 1994, p. 170.

15 Cf. John PaulII, General Audience, Evidencefor the existence of God(10.07.1985) 6.

16 Cf. ibidem.

17 John Paul II, Letter to Families 20. 
"beauty" refers to a variety of goods - it is said for example about the beauty of the body, the beauty of the spirit and virtue ${ }^{18}$.

Both beauty and good can grow up ${ }^{19}$, ie. something can be more beautiful and less beautiful, and consequently more and less good. This dynamism can be seen, moreover, in the complements which most often appear in the teaching of the Church in conjunction with the category of beauty. It is said about "integral" 20 " "original"21, "spiritual"22, "supernatural" 23 , "invisible" 24 " "difficult" 25 , "personal" beauty. This imposes immediately the question whether there is also the beauty of the "piecemeal", "secondary", "carnal", "inherent", "visible", "material", "easy". The bridegroom from the Song of Songs is calling "the whole (emphasis added. T. Z.) beautiful you are, my love" $(4,7)^{26}$. Does this mean that beauty can coexist in a man with some ugliness, flaw, which destroys this attribute at least in some areas? Asking we can go further: Is there also the beauty of evil?

\section{Can beauty be a bad thing?}

According to the Scripture, beauty is not the only argument for the perfection of God (cf. Matt 6,28-30). On the contrary, good manifests itself sometimes in the absence of beauty, eg. in the drama of Golgotha: "He had no grace or majesty to look at him, nor appearance that we would have liked (cf. Isa 53,2). Moreover, the Bible presents that the concept of beauty is sometimes synonymous of staying in sin

18 John Paul II. Apostolic Letter Augustinum Hipponensem 4.

19 Cf. Piękno, [in]: H. Vorgrimler, Nowy leksykon teologiczny, p. 264.

20 Cf. John Paul II, General Audience, Love Is Ever Seeking and Never Satisfied (6.06.1984) 2 .

21 Cf. John Paul II, General Audience, Mary Was Conceived Without Original Sin (15.05.1996) 4 .

22 Cf. John Paul II, General Audience, The Holy Spirit: Soul of the Church (28.11.1990) 5 .

23 Por. ibidem.

$24 \quad$ Cf. John Paul II, General Audience, Respect for the Work of God (21.11.1984) 4.

25 Cf. John Paul II, Speech to the professors and students of the Catholic University of Lublin (Częstochowa, 6.06.1979).

26 Cf. John Paul II, General Audience, Return to the Subject of Human Love in the Divine Plan (23.05.1984) 3. 
Moral theology (cf. Ezek. 16,2527; Dan 13,56) ${ }^{28}$. Beauty may be in the service of evil ${ }^{29}$. Wisdom literature indicates its "vanity" 0 .

This happens whenever beauty is detached from its proper source. The beauty of the things of this world can enslave a $\operatorname{man}^{31}$, and so it may receive a higher value than material things - freedom. Beautiful things are able to engage human, that it is difficult for him to function normally ${ }^{32}$, eg. to create relationships with people.

The very beauty, therefore, is not enough. It is even dangerous ${ }^{33}$. Beauty may be eclipsed ${ }^{34}$. It can be uglyfied ${ }^{35}$. Beauty is exposed to the danger of evil, when it is related not so much to the same real value but to the subjective reception. If beauty is believed that what people like, we must recognize that it may be also what is bad. The object of pleasure can also be evil. The eternal dispute "Is it something beautiful, because people like it, or it is liked because it is beautiful?" has already solved St. Augustine saying, "It is liked because it is beautiful," and not vice versa. Physical beauty is neither good nor bad. It becomes so depending on the use, that is done with $i^{36}$. It becomes bad when it hides eternal beauty, the beauty of God. Besides, there is a hierarchy of beautiful things. Evil arises when the hierarchy is disturbed or even reversed. It is needed to look for some tests of beauty; tools that will help define what is beautiful and what place it should occupy in the entire order of value. These criteria could be included in two statements: 1) beautiful is what is good, and 2) beautiful is what leads to good.

27 Ezekiel drawing a symbolic history of Israel, puts in the lips of God the reproach: "At every street corner you built your lofty shrines and degraded your beauty, spreading your legs with increasing promiscuity to anyone who passed by".

The words of Daniel to the false accusers of Susanna: "He dismissed the man, ordered the other to be brought and said to him, "Son of Canaan, not of Judah, beauty has seduced you, lust has led your heart astray!"

Cf. K. Klauza, 561.

John Paul II, General Audience, Woman's moral nobility (9.04.1996) 3. Cf. P. Turzyński, Piękno w teologii św. Augustyna, Radom 2013, p. 241.

Cf. ibidem, p. 246.

Por. X. Leon-Dufour, Kobieta, [in]: Stownik Teologii Biblijnej, X. Leon-Dufour ed., p. 379. John Paul II, General Audience, The Heart a Battlefield Between Love and Lust (23.07.1980) 6 .

35 John Paul II, Letter To the Youth of the World 10.

36 Cf. Ewolucja teologii piękna p. 50. 


\section{Good as a criterion of beauty}

It is true that in Christian morality there is not a purely aesthetic attitude to life ${ }^{37}$, ie. that beauty is not the only criterion of good (good may be, for example what is prescribed), but it can serve as a promise and exemplary cause. Christian morality is focused on the infinite Beauty. Contemplation of this Beauty, sticking to it and even love towards him is an element of hope, which become a reality in the final beatific communion with the Beauty in eternity ${ }^{38}$. On the way of achieving this state, the absolute Beauty is the first object of the promise and then a role model of behaviour which can be defined not only as good, but also as beautiful. Greek ideal of kalos-kagathos should therefore be regarded as an archetype, which should imitate reality ${ }^{39}$. The beauty of God is in fact the cause of exemplar of personal beauty.

A man is not only called to "to achieve a state of beauty", but also invited to cooperate in the creation of beauty ${ }^{40}$. It is of importance that this ability - like the whole man - has been affected by sin. A sinful man is only able to create ugliness in and around him. Therefore, it should be emphasized that what deepens the spiritual beauty is the life of grace ${ }^{41}$. Thus, the creation of beauty demands direct conversion and struggle with sin. The form of all beauty - in the words of St. Augustine - is unity ${ }^{42}$. Therefore, love of beauty must refer to unity, above all, the unity of spirit and body. In contrast, only love of the beauty of the body can lead to forgetting about the beauty of the spirit, and consequently about the beauty of the whole person.

\section{Beauty in the service of good}

The mutual relation of beauty and good has always been regarded as a kind of call to follow, realizing the ideal contained in the highest Beauty, while mentioned kalokagathia was the educational ideal

37 Cf. Piękno, [in]: H. Vorgrimler, Nowy leksykon teologiczny, p. 264.

38 Cf. ibidem.

39 Cf. J. de Vaulx, Dobro i zło, [in]: Stownik Teologii Biblijnej, X. Leon-Dufour ed., p. 208.

40 John Paul II, Speech on the occasion of the dedication of the University Warsaw Library (11.06.1999).

41 Cf. John Paul II, General Audience, Mary Shows Us God's Respect for Women (29.11.1995) 5 .

42 Cf. Paul VI, The letter proclaiming St Benedict as Patron of Europe. 
Moral theology uniting beauty and good ${ }^{43}$. The attraction of beauty lies in the fact that it leads to ethics or to a beautiful life ${ }^{44}$. Since ancient times, it was pointed out that contact with beauty causes the state of purification in the man, spiritual catharsis. Experience of beauty shapes delight ${ }^{45}$. Beauty is - as Norwid said - the shape of love" ${ }^{46}$ but also love triggers a special experience of beauty. Dostoyevsky expressed this even more "beauty will save the world"

The real beauty is always good. Being persuasive can lead to good. Acting on emotions, it works more effectively than ordinary preaching about good and evil. Outer beauty, beauty in the aesthetic sense, is a sign of inner beauty and should lead to such beauty. This is the pedagogic function. Beauty has the power of awakening moral attitudes. It arises joy. It creates bonds between people. Thus, it can play the role of the environment (locus) of impact. It therefore has an existential meaning.

There are attempts to organize the systematic theology around the category of beauty. The Swiss theologian H. U. von Balthasar treated dogma as aesthetics. He presented the entire systematic theology being focused around the category of beauty. The question is whether this methodology can be applied to the reflection on morality. Such attempts should be rather skeptical because the progressive, at least since the seventeenth century, the process of subjectivization and relativized beauty - the conviction of the impossibility of capturing and constructing a theory of beauty, or the emphasis on the subjective beauty (beautiful is what is considered as such by the viewer or listener) while questioning the objective beauty (beauty in itself ${ }^{48}$, they hinder the use of this category on the path towards good. If in fact the essence of beauty does not determine characteristics of the object, but the features and structure of the human mind (Hume) or beautiful is what is modern, ie. giving expression of the era and its real preferences (Stendhal), thus beauty only reflects the human condition

$43 \quad$ Cf. L. Gawor, p. 170.

44 Cf. John Paul II, Message of the Holy Father to the Pontifical Council for Culture on the occasion of their plenary assembly (19.11.1999) 2.

45 Cf. John Paul II, General Audience, Return to the Subject of Human Love in the Divine Plan (23.05.1984) 3.

46 Cf. John Paul II, Speech to the representatives of the world of culture (Warszawa, 13.06.1987) 5 .

$47 \quad$ Cf: LtA 16.

48 Cf. M. Michałowicz, Piękno, 2. W teorii sztuki, [in:] Encyklopedia katolicka, E. Gigilewicz et al. ed., vol. 15, 562-563. 
and contemporary culture, and does not lead to the objective good. Similarly, if considered to be only an element of variable context (like fashion) and people do not see completely present in it the element of the eternal and unchanging, it will remain only a category of the theory of art, creativity and artistic experience, but not from the field of morality. However, this does not relieve the theologians to talk beautifully about moral good.

Beauty therefore has its boundaries. The boundaries are sets by moral superiority over the aesthetic goods; eternal over the temporal, spiritual over the corporal. It is not beautiful what is pleasing to the eyes and ears, but what leads towards good. It is not beautiful what is useful, pleasant, subjective. It is beautiful what affects the moral life; which contributes to the perpetuation of moral attitudes. Beauty has a moral dimension because of the hierarchy of beings and their beauty. Where the hierarchy is compromised, the value of beauty itself becomes ambivalent or even negative. The boundaries of beauty set also use that a man makes of $i^{49}$. The man is still able to use what ontically is beautiful also for the bad things.

Moral boundaries of beauty have recently been exceeded by the absolute freedom. If in the art "anything goes", it will be increasingly difficult to find there the source of life decisions. If the art is committed to only being shocked, at least it is misleading and sometimes simply corrupts. So not every work of art, which should be in the service of beauty, is the development of moral and transmission of moral values; not every work of art discovers the beauty of the man himself and the world. Such a task will meet only such a work of art, which is the integral truth about a man. Beauty contained in the works of art should be the splendor of the truth; and only such art deserves to be called beautiful.

\section{MORALNE GRANICE PIĘKNA}

Refleksja nad pięknem powinna uwzględniać także jego aspekty moralne, a więc relację do dobra. Na wzajemny stosunek piękna i dobra wskazuje terminologia hebrajska i grecka, która tym samym słowem (hebr. tob, gr. kalos, agathos) określa zarówno piękno jak i dobro. W koncepcji arystotelesowsko-tomistycznej każdy byt jest piękny i zarazem dobry, ponieważ ma swoje źródło

$49 \quad$ Cf. P. Turzyński. Piękno w teologii św. Augustyna p. 237. 
Moral theology

w stwórczym działaniu Boga. Ze względu na dokonującą się współcześnie subiektywizację i relatywizację piękna należy podkreślić, że na to miano zasługuje jedynie to, co stanowi odbicie piękna wiecznego. Nie jest zatem piękne wszystko, co człowiek tworzy i za takie uznaje. Piękne jest to, co jest dobre i co prowadzi ku dobru. Poza tą granicą wyznaczoną przez dobro istnieje tylko piękno pozorne, a nawet brzydota, która bywa nazywana pięknem, choć nim nie jest. Dążenie ku pięknu wiecznemu, tworzenie piękna w sobie i wokół siebie, wzrastanie w pięknie jest moralnym obowiązkiem człowieka.

Słowa kluczowe: piękno, dobro, moralność.

\section{Bibliography:}

1. Ewolucja teologii piękna, http://katechetyka.diecezja.opole.pl/2014-arcydziela/04-teologia.pdf, p. 43 (30.03.2016).

2. Gawor L., Piękno, [in:] Maty stownik etyczny, S. Jedynak ed., Bydgoszcz 1994, p. 170.

3. Guillet J., Łaska, [in]: Stownik Teologii Biblijnej, X. Léon-Dufour ed., transl. K. Romaniuk, Poznań 1994, p. 437-441.

4. John Paul II, Apostolic Letter Augustinum Hipponensem (28.08.1986).

5. John Paul II, General Audience, Evidence for the existence of God (10.07.1985).

6. John Paul II, General Audience, Love Is Ever Seeking and Never Satisfied (6.06.1984).

7. John Paul II, General Audience, Mary Shows Us God's Respect for Women (29.11.1995).

8. John Paul II, General Audience, Mary Was Conceived Without Original Sin (15.05.1996).

9. John Paul II, General Audience, Respect for the Work of God (21.11.1984).

10. John Paul II, General Audience, Return to the Subject of Human Love in the Divine Plan (23.05.1984).

11. John Paul II, General Audience, The Heart a Battlefield Between Love and Lust (23.07.1980).

12. John Paul II, General Audience, The Holy Spirit: Soul of the Church (28.11.1990).

13. John Paul II, General Audience, Woman's moral nobility (9.04.1996).

14. John Paul II, Letter to Families (2.02.1994).

15. John Paul II, Letter to the Artists (4.04.1999).

16. John Paul II, Letter To the Youth of the World (31.03.1985).

17. John Paul II, Message of the Holy Father to the Pontifical Council for Culture on the occasion of their plenary assembly (19.11.1999).

18. John Paul II, Speech on the occasion of the dedication of the University Warsaw Library (11.06.1999).

19. John Paul II, Speech to the professors and students of the Catholic University of Lublin (Częstochowa, 6.06.1979). 
20. John Paul II, Speech to the representatives of the world of culture (Warszawa, 13.06.1987).

21. Klauza K., Piękno, 1. W teologii, [in:] Encyklopedia katolicka, E. Gigilewicz et al. ed., vol. 15, 561-562.

22. Leon-Dufour X., Kobieta, [in]: Stownik Teologii Biblijnej, X. Leon-Dufour ed., p. 377-381.

23. Michałowicz M., Piękno, 2. W teorii sztuki, [in:] Encyklopedia katolicka, E. Gigilewicz et al. ed., vol. 15, 562-564.

24. Mollat D., Chwata, [in]: Stownik Teologii Biblijnej, X. Leon-Dufour ed., theology p. 134-140.

25. Paul VI, The letter proclaiming St Benedict as Patron of Europe (24.10.1964).

26. Piękno, [in]: H. Vorgrimler, Nowy Leksykon Teologiczny, transl. T. Mieszkowski, P. Pachciarek, Warszawa 2005, p. 264.

27. Turzyński P., Piękno w teologii św. Augustyna, Radom 2013.

28. Vaulx J. de, Dobro i zło, [in]: Stownik Teologii Biblijnej, X. Léon-Dufour ed., p. 207-210. 